\title{
Impact response of laminate cylindrical shells
}

\author{
Carlos A.C.P. Coelho, Fábio V.P. Navalho \\ ESTA, Escola Superior de Tecnologia de Abrantes, Instituto Politécnico de Tomar, Tomar, Portugal \\ cccampos@ipt.pt,fabionavalbo@gmail.com
}

P.N.B. Reis

C-MAST, Depart. of Electromechanical Engineering, University of Beira Interior, Covilhã, Portugal preis@ubi.pt,bttp://orcid.org/0000-0001-5203-3670

ABSTRACT. Composite laminates subjected to low-velocity impact events on the through-thickness direction are conveniently studied and disseminated in the open literature. However, in terms of laminate cylindrical shells this subject is less common. Therefore, the main goal of the present work is to study the impact response of laminate composite cylindrical shells composed by different type of fibres. For this purpose, laminates with different configurations $(6 \mathrm{C}, 2 \mathrm{C}+2 \mathrm{~K}+2 \mathrm{C}$ and $2 \mathrm{C}+2 \mathrm{G}+2 \mathrm{C})$, where the "number" represents the number of layers used and $\mathrm{C}=$ Carbon, $\mathrm{K}=$ Kevlar and $G=$ Glass fibre layers, were analysed in terms of static and impact strength. It is possible to conclude that both static and impact performance are strongly influenced by the shells' configuration. In terms of compressive static strength, the Kevlar hybrid shells present values $53.2 \%$ higher than the $6 \mathrm{C}$ shells, while the glass hybrid shells present values $17.3 \%$ lower. The impact analyses shows, regardless the similarity of the maximum loads for all configurations, that Kevlar hybrid shells achieved the highest elastic recuperation and the glass hybrid shells the maximum displacement.

KEYwORDS. Impact strength; Composites; Cylindrical shells; Mechanical testing.

\section{OPEN@ACCESS}

Citation: Coelho, C.A.C.P., Navalho, F.V.P., Reis, P.N.B., Impact response of laminate cylindrical shells, Frattura ed Integrità Strutturale, 48 (2019) 411-418.

Received: 15.12 .2018

Accepted: 21.01.2019

Published: 01.04.2019

Copyright: (C) 2019 This is an open access article under the terms of the CC-BY 4.0, which permits unrestricted use, distribution, and reproduction in any medium, provided the original author and source are credited.

\section{INTRODUCTION}

$\mathrm{C}$ omposite materials, day after day, are increasingly replacing the traditional metallic materials in several engineering applications, and this tendency will continue as consequence of their high stiffness and strength, low weight, adjustable properties, competitive cost, good static and dynamic properties, good resistance to corrosion and simplified fabrication. 
However, the main disadvantages of those materials are related with their poor compression and transverse properties [1, 2]. In this context, literature reports a high sensitivity of these materials to low-velocity impact events that occur easily inservice or during the maintenance activities. These type of events are responsible by damages that are difficult to detect [3, 4] and, simultaneously, responsible by significant reductions of the residual mechanical properties [5-8]. Studies about composite laminates subjected to low-velocity impact events on the through-thickness direction are abundant in the literature, especially in terms of damage characterization [9-12], compression-after-impact [13], multi-impacts [14], environmental effects [15-17] and numerical investigations [18, 19]. On the other hand, literature also presents strategies to improve their impact performance with resource to hybridisation [20-22] or using nano-enhanced resins [23-27]. However, the impact characterization in all these works was performed in composite plates. The analysis of laminate cylindrical shells, are less disseminated in the open literature, but this topic should be empathized due to the complexity and design of many advanced structures.

Gong et al. [28], for example, developed an analytic solution to predict the response of laminate shells subjected to impact loads. This solution included both contact deformation and transverse shear deformation and it was used to study the effects of different impact conditions and shell size, as well as the curvature's effect, on the contact force and central deflection of the shell. Results were compared with those reported in the literature and good agreement was found. An experimental study was developed by Kistler [29] and he noticed that the geometry strongly influences the impact response. Stiffer structures have higher impact strength, smaller centre deflections and shorter contact time. A threedimensional eight-node non-conforming element with Taylor's modification was used by Zhao and Cho [30] to analyse the interlaminar stress distribution, initial damage pattern and progressive failure on laminate composite shells subjected to impact loads. The stiffness effect was also studied by Arachchige et al. [31,32] and the results shown that the impact load increases with increasing stiffness while the contact time decreases. Regarding the velocity of impact, it was verified a direct relationship with the contact load. Kistler and Waas [33] studied the impact behaviour of cylindrical graphite/epoxy panels with different thicknesses, curvatures and support conditions. They concluded that increasing the thickness leads to increased stiffness and, consequently, higher impact force as well as lower deflection and contact time. Krishnamurthy et al. $[34,35]$ studied the damage and the impact response of cylindrical graphite/epoxy shells using the finite element method. According with the study developed, higher mass values of the impactor are responsible by the increasing of the contact time and the damage occurred under the impact point. A nonlinear finite element analysis of impact response and impact-induced damage in curved composite laminates subjected to transverse impact by a foreign object was developed by Kumar [36]. It was possible to conclude that the impact response is significantly dependent on the shell curvature.

Therefore, this study intends to improve the knowledge related to the impact response of hybrid composite cylindrical shells. Combining two or more fibre types, hybridisation is a promising strategy to toughen composite materials, and a better balance of the mechanical properties is obtained relatively to non-hybrid composites. For this purpose, laminates with the same number of layers, but composed by different type of fibres, were manufactured and conveniently characterized in terms of static and impact strength. Both loading modes were tested with the same boundary conditions, where the curved edges of the test specimens were free while the straight edges were supported.

\section{EXPERIMENTAL PROCEDURE}

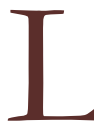

aminate composite cylindrical shells were manufactured by hand lay-up and overall dimensions are shown in Fig 1. A system of SR1500 epoxy resin and a SD2503 hardener standard, both supplied by Sicomin (Châteauneuf-les-

Martigues, France), was used with six layers, all in the same direction, of bi-directional woven fabrics to produce the specimens. Three different typologies were investigated with the following stacking sequence: $6 \mathrm{C} ; 2 \mathrm{C}+2 \mathrm{~K}+2 \mathrm{C}$ and $2 \mathrm{C}+2 \mathrm{G}+2 \mathrm{C}$, where the "number" represents the number of layers used and $\mathrm{C}=$ Carbon (taffeta with $196 \mathrm{~g} / \mathrm{cm}^{2}$ ), $\mathrm{K}=$ Kevlar (taffeta with $281 \mathrm{~g} / \mathrm{cm}^{2}$ ) and $\mathrm{G}=$ Glass (taffeta with $205 \mathrm{~g} / \mathrm{cm}^{2}$ ) fibre layers. Carbon bi-directional woven fabrics were supplied by CIT (Legnano, Italy), while the Kevlar woven fabrics were supplied by DuPont (Richmond, USA) and glass fibre woven fabrics by Porcher Industries Germany (Erbach, Germany). The system was placed inside a vacuum bag for 24 hours and a maximum pressure of 0.5 mbar was applied for 9 hours in order to maintain a constant fibre volume fraction and an uniform laminate thickness, beyond to eliminate any air bubbles existing in the laminate. According the supplier's datasheet, the post-cure was carried out in an oven at $60^{\circ} \mathrm{C}$ for $16 \mathrm{~h}$. The $\mathrm{T}_{\mathrm{g}}$ of the resin is about $70^{\circ} \mathrm{C}$.

Low-velocity impact tests were performed using a drop weight-testing machine IMATEK-IM10 (Old Knebworth, United Kingdom). More details of the impact machine can be found in [37]. An impactor diameter of $10 \mathrm{~mm}$ with a mass of $2.826 \mathrm{~kg}$ was used. As shown in Fig. 2, the impact will occur at the centre of the samples with free support of the curved edges while the straight edges are bi-supported. The impact energy used was $5 \mathrm{~J}$, which corresponds to an impact velocity 
of $1.88 \mathrm{~ms}^{-1}$. This energy was previously selected in order to promote damage, but without perforation of the specimens. The impact tests were performed according to ASTM D7136 standard and, for each configuration, five specimens were tested at room temperature. Flexural tests were also performed using a Shimadzu AG-100 universal testing machine (Kyoto, Japan), with the same support and loading nose shown in Fig. 2, equipped with a $100 \mathrm{kN}$ load cell at a displacement rate of $3 \mathrm{~mm} / \mathrm{min}$. All tests were also carried out at room temperature, and five specimens were tested for each configuration. All results will be discussed in terms of average values.

a)

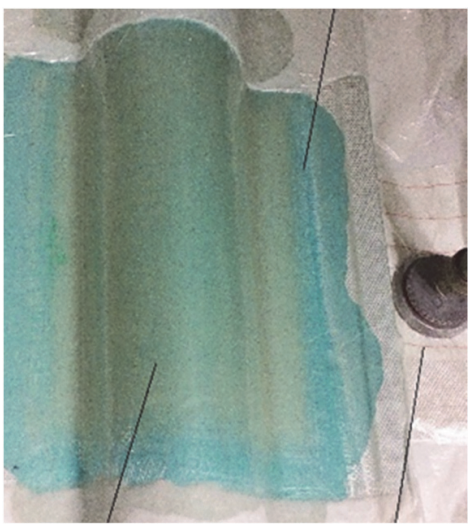

$\varnothing 106$

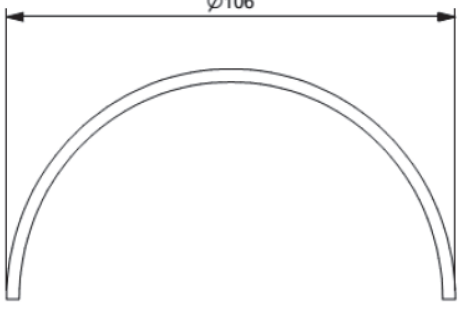

b)

Figure 1: a) View of the manufacturing process and mold; b) Geometry and dimensions of the specimens (thickness $1.4 \pm 0.1 \mathrm{~mm}$ ).

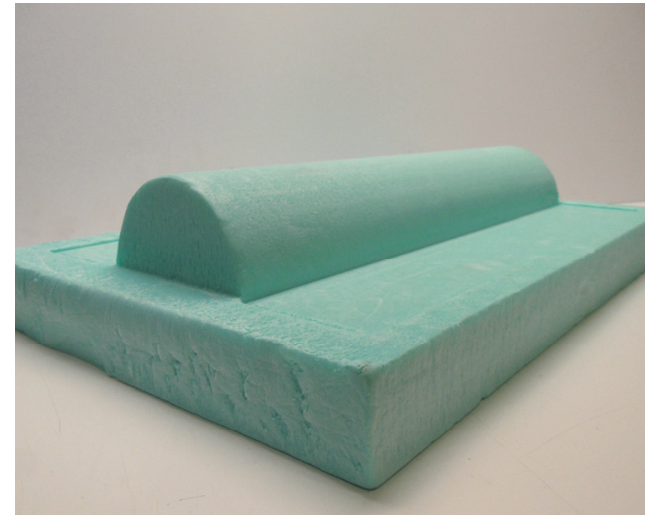

100

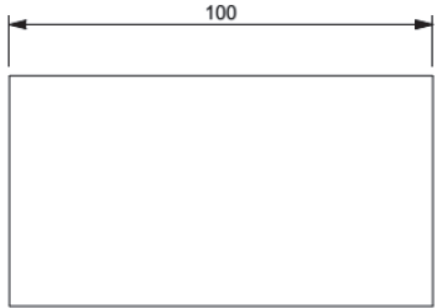

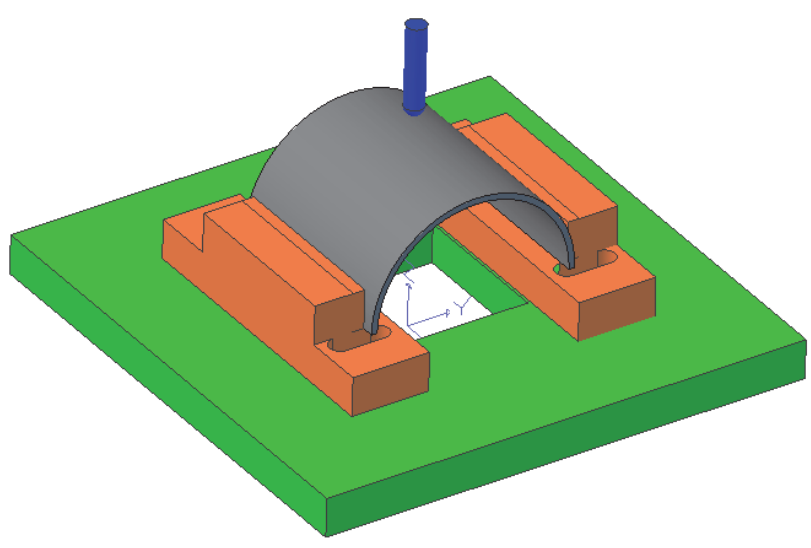

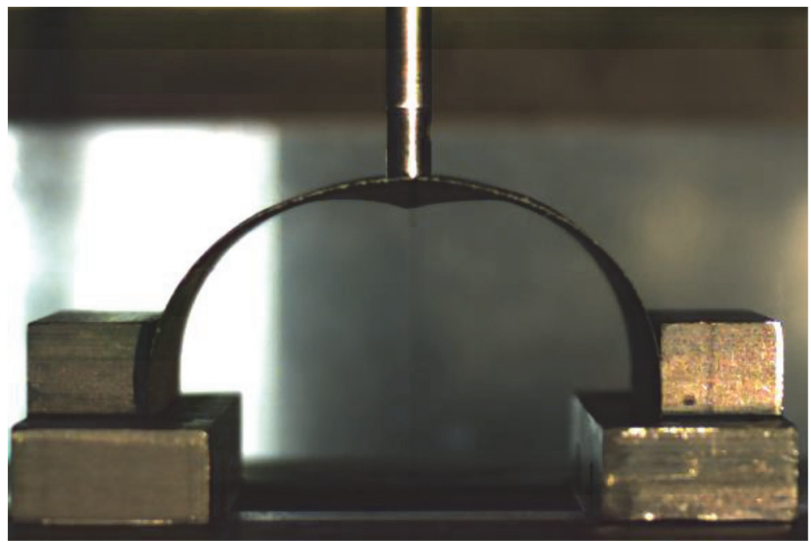

Figure 2: General views of the apparatus (support) used in the experimental tests.

\section{RESULTS AND DISCUSSION}

I $\mathrm{n}$ order to understand the impact performance of the different laminate composite semi-cylindrical shells, flexural tests were carried out for each configuration. Fig. 3 shows typical load-displacement curves and Tab. 1 presents the average results, with the respective standard deviation. Stiffness was defined as the slope in the linear region of the load-displacement response and the displacement is the value obtained for the maximum load. 


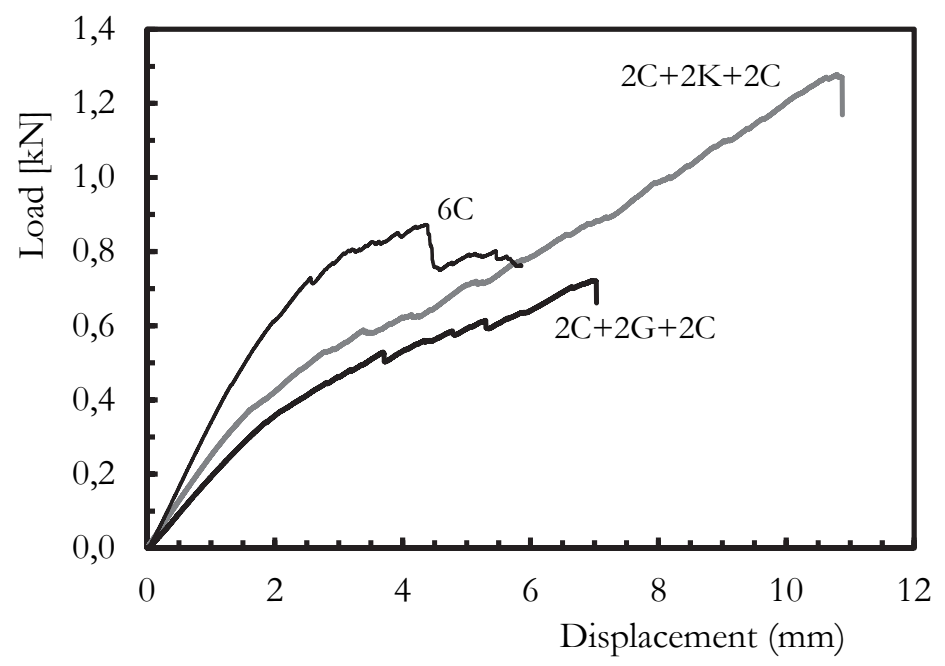

Figure 3: Typical load-displacement curves for the different configurations.

It is possible to observe a linear region in all curves shown in Fig. 3, which is longer for the non-hybrid laminates. The stiffness presents the highest value for the non-hybrid composite semi-cylindrical shells, while the lowest value occurs for hybrid composite shells involving carbon and glass fibres. According with the literature [38], the zigzag aspect of the curves represents fractures of the fibres, in compression, and some delaminations around the broken fibres are also expected. The high compressive stress concentration at the loading nose contact region associated with the low compressive strength of the fibres promotes the failure damage described previously.

\begin{tabular}{ccccccc}
\hline \multirow{2}{*}{ Laminates } & \multicolumn{2}{c}{ Maximum Load $[\mathrm{N}]$} & \multicolumn{2}{c}{ Displacement at Max. Load $[\mathrm{mm}]$} & \multicolumn{2}{c}{ Stiffness $[\mathrm{N} / \mathrm{mm}]$} \\
\cline { 2 - 7 } & Average & Std. & Average & Std. & Average & Std. \\
6C & 873 & 121 & 4.4 & 1.0 & 354 & 41 \\
$2 \mathrm{C}+2 \mathrm{~K}+2 \mathrm{C}$ & 1337 & 203 & 11.3 & 3.1 & 252 & 62 \\
$2 \mathrm{C}+2 \mathrm{G}+2 \mathrm{C}$ & 722 & 184 & 7.1 & 1.9 & 203 & 54 \\
\hline
\end{tabular}

Table 1: Compressive strength of the different laminate composite semi-cylindrical shells.

The maximum average load obtained in the hybrid carbon and Kevlar fibres shells is $53.2 \%$ higher than the maximum load obtained in the non-hybrid shells, while this parameter for hybrid shells with carbon and glass fibres is $17.3 \%$ lower. In terms of stiffness, the highest average value occurs for shells with carbon fibres $(354 \mathrm{~N} / \mathrm{mm})$ followed by the hybrid configurations that involve Kevlar fibres and glass fibres with values, respectively, $28.8 \%$ and $42.7 \%$ lower. Finally, the lowest maximum average displacement occurs for shells with carbon (about $4.4 \mathrm{~mm}$ ) and this value increases $38 \%$ and $156.8 \%$, respectively, for shells with carbon and glass fibres and shells with carbon and Kevlar fibres. The intrinsic mechanical properties of the fibres and the damage mechanisms justify the tendency described previously. Dong et al. [39] observed a flexural modulus decreasing with higher percentage of glass fibres and positive hybrid effects by substituting carbon fibres with glass fibres. According to Giancaspro et al. [40], carbon fibre composites fail mainly on the compression side, while glass fibre composites fail on the tension side. Therefore, adding carbon fibres on the tension side of glass fibre composites increase the flexural strength, but when they are added on the compressive side the failure mode changes from tensile to crushing. On the other hand, literature reports that there is an optimal content of glass fibre to achieve maximum flexural strength [40, 41]. According to Dong et al. [41], for carbon/glass hybrid composites, this value is around $12.5 \%$ when all glass fibres are placed on the compressive side.

Impact tests were carried out and Fig. 4 shows the force-time curves for each configuration. The curves that can be observed are similar with those find in literature [23-25]. The curves contain oscillations that, according Schoeppner and Abrate [42], result from the elastic wave and are created by the vibrations of the samples. It depends on the stiffness and on the mass of the specimen and impactor being excited by the rapid variation of the cinematic magnitudes at the time of collision [43]. 


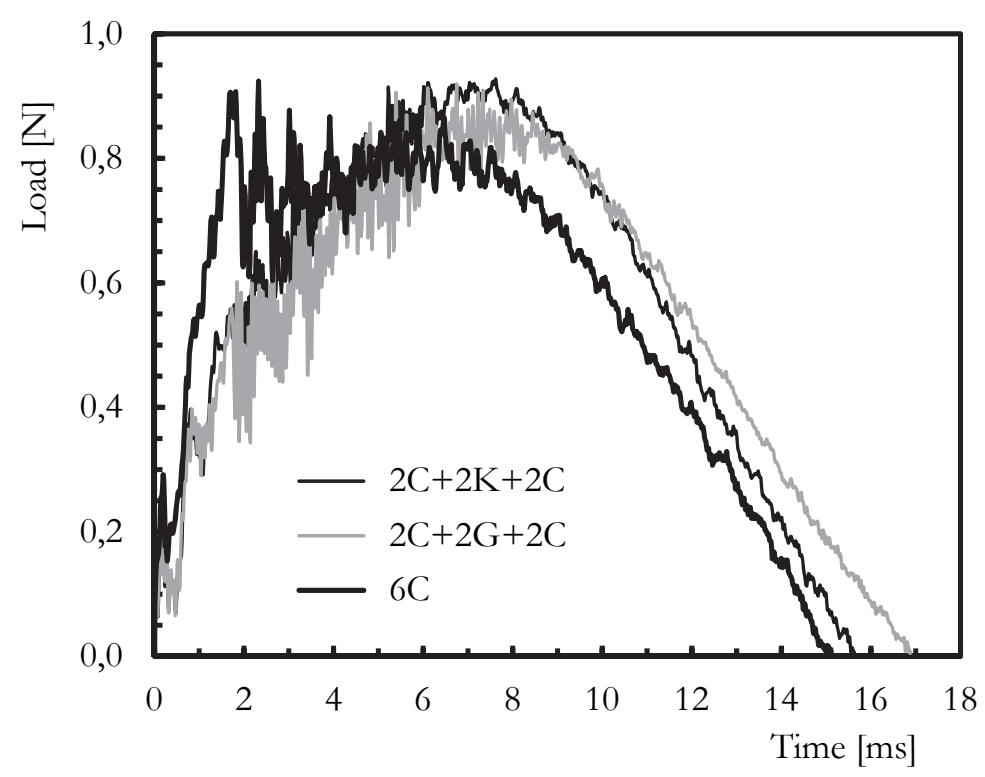

Figure 4: Typical load-time curves for the different configurations.

In detail, for the hybrid shells, it is possible to observe that the load increases up to a maximum value ( $\left.P_{\max }\right)$ followed by a drop after the peak load. On the other hand, for shells only with carbon fibres after $\mathrm{P}_{\max }$ the load decreases and remains practically constant while the time increases. This untypical curve, compared with the other two, means that major damage occurs but with a non-perforating impact event. According with the literature [25], the value of $\mathrm{P}_{\max }$ is very dependent of the impact energy and represents the peak load value that the composite laminate can tolerate, under a particular impact level, before undergoing major damage. Fig. 5 shows the typical energy-time curves, where it is possible to observe that the impact energy was not high enough to infringe full penetration.

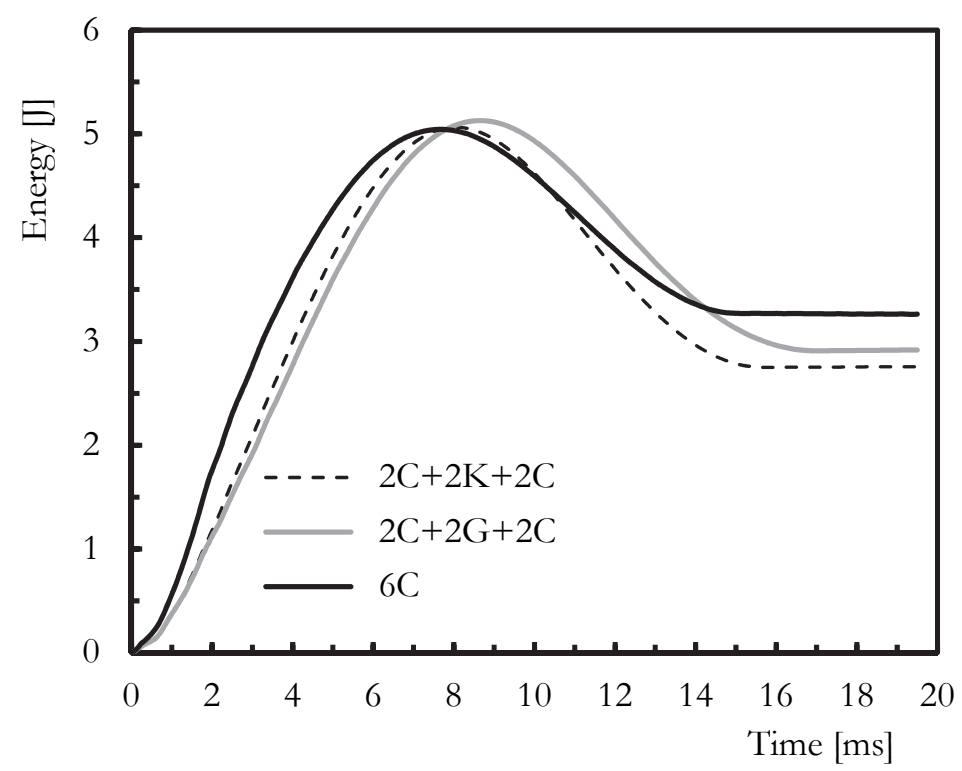

Figure 5: Typical energy-time curves for the different configurations.

In all tests, the impactor sticks the specimens and rebound (non-perforating impact). The beginning of the plateau coincides with the loss of contact between the striker and the specimen, so, this value is the energy absorbed by the specimen $[11,25]$. In this context, as reported previously, the non-hybrid specimens present the highest absorbed energy, 
consequently higher damages, and the hybrid specimens involving the carbon and Kevlar fibres are the ones that present the lowest absorbed energy.

Tab. 2 presents the average values, and respective standard deviation, of the peak load, of the maximum displacement and the rebounded energy (elastic recuperation). The elastic recuperation is the difference between the absorbed energy and the energy at peak load [23].

\begin{tabular}{ccccccc}
\hline \multirow{2}{*}{ Laminates } & \multicolumn{2}{c}{ Peak Load $[\mathrm{N}]$} & \multicolumn{2}{c}{ Max Displacement $[\mathrm{mm}]$} & \multicolumn{2}{c}{ Elastic recuperation [] } \\
\cline { 2 - 7 } & Average & Std. & Average & Std. & Average & Std. \\
6C & 0.924 & 0.12 & 7.8 & 1.9 & 1.71 & 0.91 \\
$2 \mathrm{C}+2 \mathrm{~K}+2 \mathrm{C}$ & 0.920 & 0.16 & 8.9 & 0.8 & 2.35 & 0.72 \\
$2 \mathrm{C}+2 \mathrm{G}+2 \mathrm{C}$ & 0.916 & 0.21 & 9.5 & 3.1 & 2.14 & 0.98 \\
\hline
\end{tabular}

Table 2: Average values of the peak load, maximum displacement and elastic recuperation.

From Tab. 2, it is possible to observe that the maximum load $\left(\mathrm{P}_{\max }\right)$ is very close for all configurations with an average value of $0.920 \mathrm{~N}$. With more detail, it is evident a light increasing of the average maximum load (from 0.916 to $0.924 \mathrm{~N}$ ) with the stiffness of the laminate (from 203 to $354 \mathrm{~N} / \mathrm{mm}$ ), as reported in Tab. 1. On the other hand, the average maximum displacement has higher amplitude of values. The lowest value observed occurs for the non-hybrid shells, while the highest is for the stacking sequence of $2 \mathrm{C}+2 \mathrm{G}+2 \mathrm{C}$. This difference is around $21.8 \%$, but when compared the $6 \mathrm{C}$ and $2 \mathrm{C}+2 \mathrm{~K}+2 \mathrm{C}$ configurations the difference is only $14 \%$. In fact, according with the literature, stiffer structures produce higher impact forces, smaller deflections, and shorter contact duration times [29, 33, 36, 44, 45]. The geometry of a laminate composite structure, boundary conditions and material properties strongly influences its impact response [29]. For example, the impact response is found to be significantly dependent on the shell curvature, where flatter panels respond to impact with larger peak forces than more curved panels, as well as smaller peak displacements and contact durations [33]. Furthermore, changing the boundary conditions from clamped to simply supported decreases the peak impact force, and increases the peak displacement and contact duration [33]. Finally, as consequence of higher damages, the elastic recuperation of the carbon shells is the lowest of all laminates $(1.71 \mathrm{~J})$, while the $2 \mathrm{C}+2 \mathrm{~K}+2 \mathrm{C}$ configuration presents the highest elastic recuperation $(37.4 \%$ higher). According to Zhao and Cho [30], the damage appears at the top ply first and then propagates into bottom layers, however, the maximum damage area occurs at the top surface. Additional to that, as reported previously, the severity of the damage is higher because carbon fibres fail mainly on the compression side in composites exposed to bending mode [40]. In terms of the stacking sequence and number of interfaces, Zhao and Cho [30] observed that the dynamic response and impact-induced damage of composite shells are also very sensitive to these parameters. Cross-ply laminate suffers less damage, but the effect of ply orientation change on the maximum contact force reveals to be small [34]. Therefore, an optimization process in design is required, because the minimum damage zone is achieved for equal bending stiffness in both axial and circumferential directions [30]. Finally, a comparative study carried out by Zhao and Cho [30] between a laminate composite shell against a similar plate with the same dimensions and impact conditions shows different damage propagations; while the damage propagates from the outer layer into the inner layers for the shell, the damage appears at the bottom layer and propagates from the bottom to middle layer for the plate.

\section{CONCLUSIONS}

7 his study analysed the impact response of laminate composite semi-cylindrical shells composed by different type of fibres. It was possible to conclude that the static properties are strongly influenced by the shells' configuration. Shells only with carbon fibres present the highest stiffness and the lowest displacement at maximum load, but, when the glass fibre is incorporated, the lowest stiffness is obtained. On the other hand, the Kevlar fibres are responsible by the highest maximum load and displacement. In terms of impact performance, the configuration that involves the Kevlar fibres is responsible by the highest elastic recuperation, while the non-hybrid shells evidence the lowest rebounded energy. 


\section{REFERENCES}

[1] Reis, P.N.B., Ferreira, J.A.M., Costa, J.D.M., Richardson, M.O.W. (2009). Fatigue life evaluation for carbon/epoxy laminate compositesunder constant and variable block loading, Compos. Sci. Technol., 69, pp. 154-160. DOI: $10.1016 /$ j.compscitech.2008.09.043.

[2] Reis, P.N.B., Neto, M.A., Amaro A.M. (2018). Effect of the extreme conditions on the tensile impact strength of GFRP composites, Compos. Struct., 188, pp. 48-54. DOI: 10.1016/j.compstruct.2018.01.001.

[3] Adams, R.D., Cawley, P.D.R.D. (1998) A review of defects types and non-destructive testing techniques for composites and bonded joints, NDT\&E Int., 21, pp. 208-222. DOI: 10.1016/0308-9126(88)90333-1.

[4] Amaro, A.M., Reis, P.N.B., de Moura, M.F.S.F., Santos, J.B. (2012). Damage detection on laminated composite materials using several NDT techniques, Insight, 54, pp. 14-20. DOI: 10.1784/insi.2012.54.1.14.

[5] de Moura, M.F.S.F., Marques, A.T. (2002). Prediction of low velocity impact damage in carbon-epoxy laminates, Compos. Part A Appl. S., 33, pp. 361-368. DOI: 10.1016/S1359-835X(01)00119-1.

[6] Reis, P.N.B., Ferreira, J.A.M., Antunes, F.V., Richardson, M.O.W. (2009). Effect of interlayer dalamination on mechanical behavior of carbon/epoxy laminates, J. Compos. Mater., 43, 2609-2621.

DOI: $10.1177 / 0021998309344649$.

[7] Amaro, A.M., de Moura, M.F.S.F., Reis, P.N.B. (2006). Residual strength after low velocity impact in carbon-epoxy laminates, Mater. Sci. Forum, 514-516, pp. 624-628. DOI: 10.4028/www.scientific.net/MSF.514-516.624.

[8] Amaro, A.M., Reis, P.N.B., de Moura, M.F.S.F. (2011). Delamination effect on bending behaviour in carbon-epoxy composites, Strain, 47, pp. 203-208. DOI: 10.1111/j.1475-1305.2008.00520.x.

[9] Richardson, M.O.W., Wisheart, M.J. (1996). Review of low-velocity impact properties of composite materials, Compos. Part A-Appl. S., 27, pp. 1123-1131. DOI: 10.1016/1359-835X(96)00074-7.

[10] Río, T.G., Zaera, R., Barbero, E., Navarro, C. (2005). Damage in CFRPs due to low velocity impact at low temperature, Compos. Part B-Eng., 36, pp. 41-50. DOI: 10.1016/j.compositesb.2004.04.003.

[11] Aktas, M., Atas, C., Icten, B.M., Karakuzu, R. (2009) An experimental investigation of the impact response of composite laminates, Compos. Struct., 87, pp. 307-313. DOI: 10.1016/j.compstruct.2008.02.003.

[12] Dhakal, H.N., Zhang, Z.Y., Bennett, N., Reis, P.N.B. (2012). Low-velocity impact response of nonwoven hemp fibre reinforced unsaturated polyester composites: influence of impactor geometry and impact velocity, Compos. Struct., 94, pp. 2756-2763. DOI: 10.1016/j.compstruct.2012.04.004.

[13] Kulkarni, M.D., Goel, R., Naik, N.K. (2011). Effect of back pressure on impact and compression after-impact characteristics of composites, Compos. Struct., 93, pp. 944-951. DOI: 10.1016/j.compstruct.2010.06.027.

[14] Amaro, A.M., Reis, P.N.B., de Moura, M.F.S.F., Neto, M.A. (2013). Influence of multi-impacts on GFRP composites laminates, Compos. Part B-Eng., 52, pp. 93-99. DOI: 10.1016/j.compositesb.2013.03.041.

[15] Amaro, A.M., Reis, P.N.B., Neto, M.A., Louro, C. (2013). Effects of alkaline and acid solutions on glass/epoxy composites, Polym. Degrad. Stabil., 98, pp. 853-862. DOI: 10.1016/j.polymdegradstab.2012.12.029.

[16] Mortas, N., Er, O., Reis, P.N.B., Ferreira, J.A.M. (2014). Effect of corrosive solutions on composites laminates subjected to low velocity impact loading, Compos. Struct., 108, pp. 205-211. DOI: 10.1016/j.compstruct.2013.09.032.

[17] Amaro, A.M., Reis, P.N.B., Neto, M.A. (2016). Experimental study of temperature effects on composite laminates subjected to multi-impacts, Compos. Part B-Eng., 98, pp. 23-29. DOI: 10.1016/j.compositesb.2016.05.021.

[18] Aslan, Z., Karakuzu, R., Okutan, B. (2003). The response of laminated composite plates under low-velocity impact loading, Compos. Struct., 59, pp. 119-127. DOI: 10.1016/S0263-8223(02)00185-X.

[19] Karakuzu, R., Erbil, E., Aktas, M. (2010). Impact characterization of glass/epoxy composite plates: An experimental and numerical study, Compos. Part B-Eng., 41, pp. 388-395. DOI: 10.1016/j.compositesb.2010.02.003.

[20] Hosur, M.V., Adbullah, M., Jeelani, S. (2005). Studies on the low-velocity impact response of woven hybrid composites, Compos. Struct., 67, pp. 253-262. DOI: 10.1016/j.compstruct.2004.07.024.

[21] Halvorsen, A., Salehi-Khojn, A., Mahinfalah, M., Nakhaei-Jazar, R. (2006). Temperature effects on the impact behavior of fiberglass and fiberglass/Kevlar sandwich composites, Appl. Compos. Mater., 13, pp. 369-383. DOI: $10.1007 /$ s10443-006-9023-x.

[22] Salehi-Khojin, A., Mahinfalaha, M., Bashirzadeh, R., Freeman, B. (2007). Temperature effects on Kevlar/hybrid and carbon fiber composite sandwiches under impact loading, Compos. Struct., 78, pp. 197-206.

DOI: 10.1016/j.compstruct.2005.09.005.

[23] Ávila, A.F., Soares, M.I., Neto, A.S. (2007). A study on nanostructured laminated plates behavior under low-velocity impact loadings, Int. J. Impact Eng., 34, pp. 28-41. DOI: 10.1016/j.ijimpeng.2006.06.009. 
[24] Iqbal, K., Khan, S.-U., Munir, A., Kim, J.-K. (2009). Impact damage resistance of CFRP with nanoclay-filled epoxy matrix, Compos. Sci. Technol., 69, pp. 1949-1957. DOI: 10.1016/j.compscitech.2009.04.016.

[25] Reis, P.N.B., Ferreira, J.A.M., Santos, P., Richardson, M.O.W., Santos, J.B. (2012). Impact response of Kevlar composites with filled epoxy matrix, Compos. Struct., 94, pp. 3520-3528. DOI: 10.1016/j.compstruct.2012.05.025.

[26] Reis, P.N.B., Ferreira, J.A.M., Zhang, Z.Y., Benameur, T., Richardson, M.O.W. (2013). Impact response of Kevlar composites with nanoclay enhanced epoxy matrix, Compos. Part B-Eng., 46, pp. 7-14.

DOI: 10.1016/j.compositesb.2012.10.028.

[27] Reis, P.N.B., Ferreira, J.A.M., Zhang, Z.Y., Benameur, T., Richardson, M.O.W. (2014). Impact strength of composites with nano-enhanced resin after fire exposure, Compos. Part B-Eng., 56, pp. 290-295.

DOI: https://doi.org/10.1016/j.compositesb.2013.08.048.

[28] Gong, S., Toh, S., \& Shim, V. (1994). The elastic response of orthotropic laminated cylindrical shells to low-velocity impact, Compos. Eng., 4, pp. 247-266. DOI: 10.1016/0961-9526(94)90030-2.

[29] Kistler, L. (1994). Experimental investigation of the impact response of cylindrically curved laminated composite panels, AIAA paper, 94-1604-CP, pp. 2292-7.

[30] Zhao, G., Cho, C. (2007). Damage initiation and propagation in composite shells subjected to impact, Compos. Struct., 78, pp. 91-100. DOI: 10.1016/j.compstruct.2005.08.013.

[31] Arachchige, B., Ghasemnejad, H., Augousti, A.T. (2016). Theoretical approach to predict transverse impact response of variable-stiffness curved composite plates, Compos. Part B-Eng., 89, pp. 34-43.

DOI: 10.1016/j.compositesb.2015.11.036.

[32] Arachchige, B., Ghasemnejad, H. (2017). Post impact analysis of damaged variable-stiffness curved composite plates, Compos. Struct., 166, pp. 12-21. DOI: 10.1016/j.compstruct.2017.01.018.

[33] Kistler, L.S., Waas, A.M. (1998). Experiment and analysis on the response of curved laminated composite panels subjected to low velocity impact. Int. J. Impact Eng., 21, pp. 711-736. DOI: 10.1016/S0734-743X(98)00026-8.

[34] Krishnamurthy, K., Mahajan, P., Mittal, R. (2003). Impact response and damage in laminated composite cylindrical shells, Compos. Structur., 59, pp. 15-36. DOI: 10.1016/S0263-822 3(02)00238-6.

[35] Krishnamurthy, K., Mahajan, P., \& Mittal, R. (2001). A parametric study of the impact response and damage of laminated cylindrical composite shells, Compos. Sci. Technol., 61, pp. 1655-1669. DOI: 10.1016/S0266-3538(01)00015-X.

[36] Kumar, S. (2008). Analysis of impact response and damage in laminated composite shell involving large deformation and material degradation, J. Mech. Mater. Struct., 3, pp. 1741-1756. DOI: 10.2140/jomms.2008.3.1741.

[37] Amaro, A.M., Reis, P.N.B., Magalhães, A.G., de Moura, M.F.S.F. (2011). The Influence of the boundary conditions on low-velocity impact composite damage, Strain, 47, pp. e220-226. DOI: 10.1111/j.1475-1305.2008.00534.x.

[38] Reis, P.N.B., Ferreira, J.A.M., Antunes, F.V., Costa, J.D.M. (2007). Flexural behaviour of hybrid laminated composites, Compos. Part A Appl. Sci. Manuf., 38, pp. 1612-1620. DOI: 10.1016/j.compositesa.2006.11.010.

[39] Dong, C.S., Duong, J., Davies, I.J. (2012). Flexural properties of S-2 glass and TR30S carbon fiber reinforced epoxy hybrid composites. Polym. Composite., 33, pp. 773-781. DOI: 10.1002/pc.22206.

[40] Giancaspro, J.W., Papakonstantinou, C.G., Balaguru, P.N. (2010). Flexural Response of Inorganic Hybrid Composites with E-Glass and Carbon Fibers. J. Eng. Mater. Technol., 132, pp. 021005-1-021005-8. DOI: 10.1115/1.4000670.

[41] Dong, C., Davies, I.J. (2012). Optimal design for the flexural behaviour of glass and carbon fibre reinforced polymer hybrid composites. Mater. Des., 37, pp. 450-457. DOI: 10.1016/j.matdes.2012.01.021.

[42] Schoeppner, G.A., Abrate, S. (2000). Delamination threshold loads for low velocity impact on composite laminates. Compos. Part A-Appl. S., 31, pp. 903-915. DOI: 10.1016/S1359-835X(00)00061-0.

[43] Belingardi, G., Vadori, R. (2002). Low velocity impact of laminate Glass-Fiber-Epoxy matrix composite materials plates. Int. J. Impact. Eng., 27, pp. 213-229. DOI: 10.1016/S0734-743X(01)00040-9.

[44] Cho, C., Zhao, G. (1999). Dynamic response and damage of composite shell under impact, KSME Int. J., 13, pp. 596608.

[45] Her, S.-C., Liang, Y.-C. (2004). The finite element analysis of composite laminates and shell structures subjected to low velocity impact, Compos. Struct., 66, pp. 277-285. DOI: 10.1016/j.compstruct.2004.04.049. 